\title{
Implementation Processes and Performance of Livelihood Project in Bugesera Distirct Eastern Province A Case of Girinka Project
} EMMANUEL BIRINGIRO ${ }^{1}$, Dr. Dr. Safari Ernest ${ }^{2}$

\author{
${ }^{1}$ School of Business and Economics, Mount Kenya University, Kigali, Rwanda \\ ${ }^{2}$ School of School of Tourism and Hospitality Management, Mount Kenya \\ University, Kigali, Rwanda
}

DOI: 10.29322/IJSRP.11.07.2021.p115100

http://dx.doi.org/10.29322/IJSRP.11.07.2021.p115100

\begin{abstract}
The general objective of this study was to examine implementation process and performance of livelihood project in Bugesera district, Rwanda using a case Girinka project. The specific objectives are: to assess effects of beneficiaries' participation process, training process, and beneficiaries' income process on performance of livelihood project in Bugesera District-Rwanda. A descriptive research design was adopted with both quantitative and qualitative approaches. The target population comprises of 1274 beneficiaries of Girinka project in Bugesera District. A sample Size of 305 is determined. The questionnaire was employed as the key instrument for gathering information and interview guide was adopted to local authorities. Due to Covid 19 prevention measures, online data collection tool and phone interviews with the respondents were used where possible to reach administrative staff; numbers and a translated questionnaire were administered to youth community volunteers; proportions and statistics were used during data collection to make sure that the research problem is appropriately addressed. Quantitative data was analysed through the use of a computer based software known as Statistical Package for Social Sciences version 25.0. It was used for percentage, frequencies, and correlation which were used for testing the relationship between variables under study. Qualitative data was analysed using content analysis through themes and subthemes. The regression model indicates that the association between performance of livelihood project and selection of beneficiaries is positive with a coefficient of 0.165 and a constant of 1.594 . The correlation between checking completeness and performance of livelihood project has been revealed to have correlation ( $\mathrm{p}=0.000, \mathrm{t}=0.503$ ). Results indicate the correlation between cowshed management is seen to be significant ( $\mathrm{p}$ value $=0.010, \mathrm{t}=2.691$ ). A regression model shows that the association between performance of livelihood project and feeding cow (Breeding) is positive with a coefficient of 0.165 and a constant of 1.594. The correlation between cow donation (offer) and performance of livelihood project has been revealed to have correlation $(\mathrm{p}=0.000, \mathrm{t}=0.503)$. The finding revealed that holding independent variables constant (cattle shed cost, glasses costs medication cost, cost spend to water) to a constant zero, medication cost would be at .116 for performance of livelihood while the most significant $\mathrm{p}$ value was .056. In conclusion, it can be observed that the Girinka project is playing a very big role in improving livelihood in Bugesera district. The research felt effect of Girinka on nutrition improvement, milk and manure as another source of fertilizing beneficiaries' land but also changed positively their living conditions. The stud indicated intensified crops, elimination of malnutrition, increasing milk and meat production, paying dowry and re-assurance of cow possession. This study recommends that there should be enough follow up of local leaders, trainings for the beneficiaries, increasing assistance to boost effective implementation of Girinka project.
\end{abstract}

Index Terms- Implementation process, Girnka project, Livelihood, Performance, Poverty, Poverty Alleviation

\section{INTRODUCTION}

Implementation process of any project contribute to the performance of livelihood project. However, when a project reached to the implementation stage, the project team and the required financial resources to realize the project must be available and ready to do project activities (Koster, 2010). Therefore, implementation process consists of carrying out activities to deliver outputs and monitoring progress compared to the work plan. In this process, beneficiaries involvement, training and income

The growing problem around which this study turns consists in knowing if and how implementation process affect performance of livelihood project in Busesera Distrcit. In fact, Bugesera received 1811 cows (Ntanyoma, 2010). How over lack of ownership in 
identifying beneficiaries, assessing the needed skills and need budget to breed cows lead to the failure of some of them (Matiwane \&Terbinanche (2012).

In Bugesera District, there was a prolonged drought that affect harvests and cause food insecure (Uwamahoro, 2012). One of immediate interventions was the implementation of the Girinka project (Karamaga \&Rugege, 2014). After the implementation of Girinka project, research showed some livelihood improvement (UNICEF, 2011; Chauvet, et al., 2010). However, previous studies gave inconclusive results on the impact of implementation process on performance of livelihood. Umworozi (2013) reiterated that artificial insemination for all cows, good breeds of bulls found, initiation of a livestock insurance scheme were implemented, but outcomes were not favourable. In light with the above considerations, the study south to establish the effect of implementation processes on performance of livelihood project in Bugesera District using Girinka project.. The research objectives were:

i.To assess effects of beneficiaries' participation process on performance of livelihood project in in Bugesera District-Rwanda. ii.To analyze effects of training process on performance of livelihood project in Bugesera District-Rwanda.

iii.To explore effects of beneficiaries' income process in the performance of livelihood project in Bugesera District-Rwanda.

\section{REVIEW OF LITERATURE}

This section reviews previous studies conducted on implementation processes and performance of livelihood project. For instance, books, journals, websites, reports written by others on project implementation and household economic lives.

\subsection{Effect of beneficiaries' participation on performance of livelihood project}

A research conducted by Chauvet, et al, (2010) on the role of people in identification of need to be their own. The government institutions or non-governmental project owners could be careful not to enforce desires to persons or arrange for what they respect as good cause. A research of Cristina and Raquel (2016) agree that poor people necessitates are openly or closely associated with the degree of poverty within groups and families. They may be dispatched into physiological psychological, economic (job, revenue) and socio-cultural needs.

A study conducted by Vincent and Denis (2014) on continuous need-examination is pertinent to acquire the dynamic involvement of individuals in the project delivery. The need-assessment through surveys and missions in a participatory way may take into account the assessment of high expectations as seen by poor persons.

According to Ika, et al., (2010) the level of active involvement of stakeholders in managing and executing projects which mainly relies on the quality of project plan. A research undertaken by Ika, et al., (2010), the international project success criteria comprise of relevant, efficient, effective, effects and sustainable parameters. The relevance denotes the degree to which the projects gets up priorities of beneficiaries, the customers and supports.

Koster (2010) the pertinent components for the performance adopting project management principles, explained and accepted objectives, a dedicated project team and viable and flexible plan of action. The research evidenced that projects did not succeed usually due to either the project scope is not fully valued or the beneficiary expects not full unspoken (Tenstep, 2012) demonstrated that high beneficiaries' needs may be the reason behind project failure.

A study conducted by Uwamahoro (2012) argue that participation provides sustainability of the project resolving the issue that outwardly encouraged development projects usually did not succeed to withstand themselves, one the opening stage of project help or resources either diminishes or removed. The involvement was considered as the antidote to these conditions in that it may accept that local community preserve the projects active. A study undertaken in Eastern province, Ngoma Districts with the aim to assess the role of Girinka project, it was found out that $90 \%$ of families who benefited from the project remarked a use of manure in agricultural activities because of ability to fertilize the land and increase crop production (Kim et, al 2011).

\subsection{Effect of training on performance of livelihood project in Bugesera District-Rwanda.}

The study on the Productive Employment for Inclusive and Sustainable Development in European Union Countries: A Multivariate Analysis conducted by Koster (2010), have shown that there are common features and differences between the European Union member states in terms of their interrelationship between productive employment, and inclusive and sustainable development. According Matiwane and erbinanche, (2012) on the importance of community participation in an ongoing construction of school Tanzania, the study conducted at Mlali and Mzumbe ward at Morogoro. The study also recommended on the importance of community mobilization as it make the people to do joints decision regarding matter relate to their social and economic development.

The study conducted by UNICEF (2011) on Building Inclusive Financial Sector in Rwanda, it was revealed that technical and financial assistance to the central bank and to the Ministry of Finance to establish and supervise 416 Umurenge SACCOs throughout the country shows that the project is sustainable. So far, the number of adult population accessing financial services in Rwanda has increased from $21 \%$ in 2008 to $42 \%$ in 2012 as the results of inclusivity in the project. 


\subsection{Effect of beneficiaries' income in the performance of livelihood project in Bugesera District-Rwanda.}

Mnaranara (2010) based on a survey of benefiting and non-benefiting farm households in Uganda's Mpigi district, analyses the Heifer-in-Trust scheme. Although the scheme is intended to alleviate income deficiencies of the poorest rural farmers through dairy production, the actual beneficiaries tend to be the less poor because of the expenses involved. On the other hand, those who did benefit from the scheme, though better off from the start, were found to be very active and enthusiastic, and it was obvious that the scheme had made a significant contribution to dairy improvement.

Tenstep (2012) employed a propensity score-matching approach to examine the direct effects of adoption of Bacillus thuringiensis cotton on yields, pesticide demand, household income, using cross-sectional data from a survey of farmers in the Punjab province of Pakistan. The positive and significant impact of the technology on household income is consistent with the potential role of new agricultural technology in directly reducing rural poverty through increased farm household income.

Serrador (2013), investigated the impacts of electrification on the household's lighting usage, home studying, energy expenditures and income. To account for self-selection processes in the connection decision they used households from the electrified villages to estimate the probability to connect for all households - including those in the no electrified villages. Their findings indicated positive effects on home studying and income, but particularly on lighting usage.

\section{MATERIALS AND MethodS}

A descriptive research design with a correlation regression size effect was utilized because it is helpful in labelling features of wide population. This research design permits the utilization of different approaches of gathering information such as questionnaire survey and interview guide (Asiaka, 2010). Both qualitative and quantitative methods were to collect relevant information. Primary data was collected using questionnaire survey and interviews methods. Due to Covid 19 prevention measures, online data collection tool and phone interviews with the respondents were used where possible to reach administrative staff; numbers and a translated questionnaire were administered to youth community volunteers; proportions and statistics were used during data collection to make sure that the research problem is addressed.

The target population of this research consisted of beneficiaries of Girinka project in Bugesera District. The population that was target by the present research are beneficiaries of Girinka project in Bugesera District. Therefore, constantly from 2016 till 2019 , 1274 benefited from Girinka project (Bugesera, 2020). Slovin's formula was used to calculate the sample size

Eq (1):

$n=\frac{N}{1+N(e)^{2}}$

Where $\mathrm{n}=$ Sample size, $\mathrm{N}=$ Population Size and $\mathrm{e}=$ Margin Error $=0.05 ; \mathrm{n}=1274 / 1+1274(0.05) 2 ; \mathrm{n}=1274 / 1+3.185 ; \mathrm{n}=1274 / 4-385$ $\mathrm{n}=305$. Through the use of Yamane formula above mentioned where $\mathrm{e}=0.05, \mathrm{~N}=1278$, the sample size become 305 .

In this regards, respondents were gotten from a stratified sampling technique after getting strata the researcher used a simple random sampling technique to reach sampled population (Baker, 2018). Therefore, this technique was adopted to reach beneficiation of Girinka project. The researcher started editing process of responses obtained from respondents. Information from the questionnaire was given numerical values known as codes. Information from quantitative research instruments was put together into categories and recapitulated into frequencies, tables and percentages Information was subjected to tabulation for through statistical package for social sciences (SPSS). A descriptive statistics was used to provide frequency, percent distribution, tendencies and standard deviations, mean for variables. Inferential statistics were used to provide a coefficient correlation for measuring effect size-r for each objectives. The result from analysis permitted to the author to assess and recapitulate results and evidences relying on specific objectives. The following regression equation was used coefficient correlation

$\mathrm{Y}=\beta 0+\beta 1 \times 1+\beta 2 \times 2+\beta 3 \times 3+\alpha$

$\alpha$ error term

$\beta 0$ constant

$\beta 1-\beta 3$ regression coefficient

$\mathrm{X} 1=$ beneficiaries' participation,

$\mathrm{X} 2=$ beneficiaries training

$\mathrm{X} 3=$ beneficiaries' income

$\mathrm{Y}$ is performance of livelihood project

The qualitative method was employed to discuss the information collected using interview guide. The researcher classified information based on the study specific objectives and reflected in non-numerical system and present it. Qualitative information helped to support and strengthen statistical information. 


\section{RESULTS}

4.1 Assessment of the Level of Performance of Livelihood Project in Bugesera District.

Table 1 Level of Performance of Livelihood Project in Bugesera District

\begin{tabular}{|c|c|c|c|c|c|c|c|c|c|c|c|c|c|}
\hline \multirow[b]{3}{*}{ Statement } & \multirow{2}{*}{\multicolumn{2}{|c|}{$\begin{array}{l}\text { Strongly } \\
\text { Disagree }\end{array}$}} & \multirow{2}{*}{\multicolumn{2}{|c|}{ Disagree }} & \multirow{2}{*}{\multicolumn{2}{|c|}{ Not Sure }} & & & \multirow{2}{*}{\multicolumn{2}{|c|}{$\begin{array}{c}\text { Strongly } \\
\text { Agree }\end{array}$}} & \multirow[b]{3}{*}{$\mathbf{N}$} & \multirow{3}{*}{$\begin{array}{l}\text { Total } \\
\text { Mean }\end{array}$} & \multirow[b]{3}{*}{ Std } \\
\hline & & & & & & & & & & & & & \\
\hline & $\mathbf{N}$ & $\%$ & $\mathbf{N}$ & $\%$ & $\mathbf{N}$ & $\%$ & $\mathbf{N}$ & $\%$ & $\mathbf{N}$ & $\%$ & & & \\
\hline $\begin{array}{l}\text { There is an increase of } \\
\text { food security owing to } \\
\text { milk produced }\end{array}$ & 25 & 8.8 & 41 & 14.4 & 30 & 10.5 & 92 & 32.3 & 97 & 34.0 & 285 & 3.451 & 0.8746 \\
\hline $\begin{array}{l}\text { There is an increase of } \\
\text { soil fertility owing to } \\
\text { manure produced }\end{array}$ & 44 & 15.4 & 82 & 28.9 & 10 & 3.5 & 61 & 21.4 & 88 & 30.9 & 285 & 3.411 & 0.9581 \\
\hline $\begin{array}{l}\text { There is an increase of } \\
\text { business activities } \\
\text { undertake owing to } \\
\text { income from milk }\end{array}$ & 68 & 23.9 & 88 & 30.9 & 7 & 2.5 & 33 & 11.6 & 899 & 31.2 & 285 & 2.843 & 0.8052 \\
\hline
\end{tabular}

Information presented in Table 1 evidenced, 34\% strongly agreed that the food security has increased owing to milk produced by beneficiaries, $30.9 \%$ strongly agreed that soil fertility is increased owing to manure produced and utilized in Bugesera Distrcit sector has been increased. Moreover, 85. \% of household received Girinka project did not bear the habit to sell manure while the combination that inorganic fertilizer is more pertinent and relevant persons. The study evidenced that $90 \%$ of households who received cows confirmed to use manure in their farming activities owing to its pertinence in fertilizing farms and improve crop production, $31.2 \%$ agreed to have noted a recorded an increase of business activities undertaken by beneficiaries.

\subsection{Effect of Beneficiaries' Participation on performance of Livelihood project in Bugesera District}

Table 2 Beneficiaries' participation

\begin{tabular}{lll}
\hline Statement & Mean & $\begin{array}{c}\text { Standard } \\
\text { Deviation }\end{array}$ \\
\hline I have participated in the assessing beneficiaries & 3.7 & 1.3 \\
I have participated in selecting of beneficiaries & 3.9 & 1.3 \\
I have participated in the in checking the completeness of the requirements & 4.0 & 0.8 \\
I have participated in checking wealth category & 4.1 & 0.9 \\
\hline
\end{tabular}

Results indicates the standard deviation of 1.3 accorded very large extent score to participation in the assessment of beneficiaries. Furthermore, $48.2 \%$ of participants reported large extent that citizens have participated in selecting of beneficiaries. Results indicated that standard deviation of 1.3 acknowledged that people have participated in the in checking the completeness of the requirements. Furthermore, 0.9 of standard deviation evidenced that people have participated in checking wealth category.

Table 3 Regression Coefficient, Analysis

\begin{tabular}{|c|c|c|c|c|c|c|}
\hline \multirow{2}{*}{\multicolumn{2}{|c|}{ Model }} & \multirow[b]{2}{*}{ B } & $\begin{array}{l}\text { Unstandardized } \\
\text { Coefficients }\end{array}$ & $\begin{array}{l}\text { Standardized } \\
\text { Coefficient }\end{array}$ & \multirow[t]{2}{*}{$\mathrm{t}$} & \multirow[t]{2}{*}{ Sig. } \\
\hline & & & Std.Error & Beta & & \\
\hline & (Constant) & .334 & 1.059 & & 4.137 & $.000 *$ \\
\hline & Assessment & .117 & .152 & .297 & 2.691 & $.010 *$ \\
\hline 1 & Selection & .112 & .144 & .165 & 1.594 & $.015^{*}$ \\
\hline
\end{tabular}




\begin{tabular}{lrrrrr} 
Checking completeness & .059 & .122 & .503 & 4.180 & $.000^{*}$ \\
Requirements completeness & .113 & .062 & .416 & 1.809 & .074 \\
\hline
\end{tabular}

a. Dependent Variable: Performance of Livelihood in Bugesera District

The coefficient of correlation was used to measure the effect size $-r$. In this regards. Results indicate the correlation between participation in assessment is seen to be significant ( $\mathrm{p}$ value $=0.010, \mathrm{t}=2.691$ ). A regression model shows that the association between performance of livelihood project and selection of beneficiaries is positive with a coefficient of 0.165 and a constant of 1.594. The correlation between checking completeness and performance of livelihood project has been revealed to have correlation $(p=0.000$, $\mathrm{t}=0.503)$.

\subsection{Effects of Training on Performance of Livelihood project in Bugesera District-Rwanda}

Table 4 Beneficiaries' training

\begin{tabular}{lcc}
\hline Beneficiaries' training & Mean & Standard Deviation \\
\hline Construct the cow shed & 4.0 & 1.2 \\
Feed the cow & 4.0 & 1.2 \\
Process of neighbour offer & 3.6 & 3.9 \\
Disease control and prevention & 1.0 \\
\hline
\end{tabular}

The study shows kind of training and skills related to breed Cow in Bugesera District-Rwanda. Consequently, standard deviation of 1.2 indicated that beneficiaries have received training on how to construct the cow shed. Furthermore, 1.2 of standard deviation accounted that effecting training on how to feed the cow. Also, regulatory best practices were indicated by standard deviation of 1.0 as respondents received training on the process of neighbor offer.

Table 5 Regression Coefficient

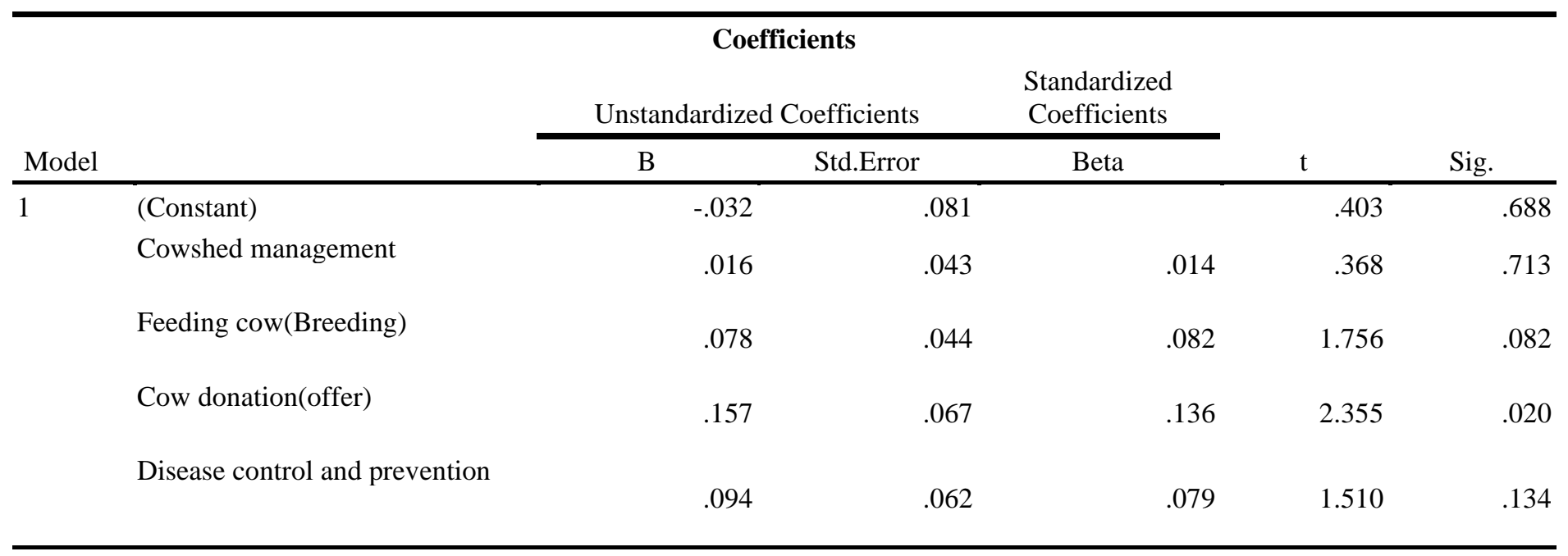

a. Dependent Variable: Performance of Livelihood Project

The coefficient of correlation was used to measure the effect size $-r$. In this regards, the results indicate the correlation between cowshed management is seen to be significant ( $\mathrm{p}$ value $=0.010, \mathrm{t}=2.691$ ). A regression model shows that the association between performance of livelihood project and feeding cow (Breeding) is positive with a coefficient of 0.165 and a constant of 1.594. The correlation between cow donation (offer) and performance of livelihood project has been revealed to have correlation ( $\mathrm{p}=0.000$, $\mathrm{t}=0.503)$. 


\subsection{Effect of Beneficiaries’ income on performance livelihood project in Bugesera District-Rwanda}

Table 6 Beneficiaries' income

\begin{tabular}{lll}
\hline Beneficiaries' income & Mean & Standard Deviation \\
\hline Availability of cattle shed cost. & 3.4 & 1.3 \\
& & 1.3 \\
Availability of grasses for cow, & 3.7 & 1.3 \\
Availability of money spending for cow medication & 3.6 & 1.2 \\
Money spending for water for the cow. & 3.8 & \\
\hline
\end{tabular}

Results presented in Table 4.6 felt that 1.3 standard deviation attribute a large extent availability of cattle shed cost. Findings show that 1.3 standard deviation show the availability of grasses for cow, in addition, 1.3 and 1.2 of standard deviation attributed large extent to the availability of money spending for cow medication.

\section{Table 7 Regression Coefficient, Analysis}

\begin{tabular}{|c|c|c|c|c|c|c|}
\hline \multirow{2}{*}{\multicolumn{2}{|c|}{ Model }} & \multicolumn{2}{|c|}{ Unstandardized Coefficients } & \multirow{2}{*}{$\begin{array}{l}\text { Standardized } \\
\text { Coefficients } \\
\text { Beta }\end{array}$} & \multirow[b]{2}{*}{$\mathrm{t}$} & \multirow[b]{2}{*}{ Sig. } \\
\hline & & B & Staf. Error & & & \\
\hline \multirow[t]{5}{*}{1} & (Constant) & 1.000 & .127 & & 7.867 & .000 \\
\hline & Cattle shed cost & .291 & .092 & .912 & 3.156 & .002 \\
\hline & Glasses costs & .387 & .102 & 1.018 & 3.779 & .000 \\
\hline & Medication cost & .072 & .056 & .213 & 1.276 & .206 \\
\hline & Cost spend to water & .037 & .056 & .162 & .655 & .514 \\
\hline
\end{tabular}

a. Dependent Variable: Performance of Livelihood Project

The coefficient of correlation was used to measure the effect size $-r$. In this regards .The finding revealed that holding independent variables constant (cattle shed cost, glasses costs medication cost, cost spend to water) to a constant zero, medication cost would be at .116 for performance of livelihood while the most significant $\mathrm{p}$ value was .056 .

\subsection{Discussion}

According to the Ministry of Agriculture and Animal Resources (MINAGRI) report published in 2019, people's involvement in Girinka project enable the community to design and implement the donations of cow based on people social category known as Ubudehe. This affect positively the living conditions of people who obtained cows. A research of Cristina and Raquel (2016) agree that poor people necessitates are openly or closely associated with the degree of poverty within groups and families. They may be dispatched into physiological (food, clothes, shelter, health) psychological (security, self-realization), economic (job, revenue) and socio-cultural needs (belongingness, entertainment to a group and social recognition) to a group).

This study is relevant with the suggestions of Roll and Jean (2014) who indicated that another benefit of participation is selfreliance where it breaks the mentality of dependency that explains more development work and in its place it ameliorates selfunderstanding.

These study findings concurred with Vincent and Denis (2014) that the presence of trainings on the scope of project activities that can be undertaken by interfacing with local leaders may lead to effective implementation of social project. The results also agree with the study of Koster (2010) the pertinent components for the performance adopting project management principles, explained and accepted objectives, a dedicated project team and viable flexible plan of action.

The overall multiple regression model demonstrated that the association between performance of livelihood project and beneficiaries' training in terms of cowshed management, feeding cow (breeding), cow donation (offer), disease control and prevention with a constant of performance of livelihood project, X1 is cowshed management, X2 is feeding cow (breeding), $\mathrm{x} 3 \mathrm{cow}$ donation (offer) and X4 is disease control and prevention. 
The present research findings concur with observations of Tenstep (2012) who noted that beneficiaries' capital which support that cow. Evidences from a research carried out one the contribution of livestock in poverty reduction in Colombia demonstrated that small farmers know cows to be pertinent in the amelioration of quality of living conditions owing to their prospective in producing milk and breed for household consumption, give manure for yields fertility and their capacity to do as strategy for savings and accumulating capital as well as their competency to decrease and expand risk owing to crop failure (Cristina \& Raquel, 2016).

The finding revealed that holding independent variables constant (cattle shed cost, glasses costs medication cost, cost spend to water) to a constant zero, medication cost would be at .116 for performance of livelihood while the most significant $p$ value was .056 .

\section{CONCLUSiOnS}

In conclusion, it can be observed that the implementation process is contributing to the performance of livelihood project in Bugesera district. Result from the present research felt that Girinka has contributed to the food security, soil fertility and business activities. The study demonstrated that Girinka contribute to the environmental protection through agro-forestry and biogas use.

Therefore, the project leads to the unity and consolidation in Rwanda but also it helped in intensifying crops, eliminating undernourishment, enhances milk production and meat, and attaining Rwandan culture to breed cows as a sign of prestige.

This study recommends that there should be enough follow up of local leaders. It would be better when the local leaders visit more often the participants for knowing what the needs or benefits and know the way forwards. There should be enough trainings for the beneficiaries, owing to the fact that most of them, it is their first time to take care of a cow.

The research findings would urge the government to encourage more organizations to do so. The research findings would also encourage other areas out of Rwanda that has not implemented such project to do so because it is one the good policies that can reduced poverty.

Public institutions and non-government organization must advance the role of using biogas in order to protect environment, there is a need to enhance aid in order facilitate local and poor people to effectively implement Girinka project. Therefore, owing to shortage of water, there is a need to give portable water to beneficiaries in Bugesera District.

Further research should be made on impact of Girinka within other Districts in Rwanda, in order to truly know what the project is bringing to the participant not only in Bugesera district, but in the whole country. In this study, the researcher had focused on crop production and household income. Further research on the impact of the project should also be made on milk production in order to know its impact on milk production in Rwanda.

\section{ACKNOWLEDGMENTS}

I wish to acknowledge Dr. Ernest Safari for her contribution to this work from the beginning up to it's the completion. I also wish to extend my acknowledgement to the Mount Kenya University, Bugesera District authorities for their support and collaborative in term of data collection

\section{REFERENCES}

[1] African Development Fund. (2011). Livestock Infrastructure Support Project in Africa. Appraisal Report. African Development Fund. Tunis, Tunisia.

[2] Asika, N. (2010). Research Methodology in the Behavioural Sciences. Ikeja: Longman

[3] Baker (2018). How to Research, $2^{\text {nd }}$ Ed. (Open University Press, Celtic Court 22 Ballmoor Buckingham MK18 1XW)

[4] Bugesera (2020). Girinka Government of Rwanda Annual Report_2010-2011.Bugesera. Rwanda

[5] Chauvet, L, Coller, P., \& Duponchel, M. (2010). What explains aid project success in post-conflict situation? The World Bank Policy Research. International Journal of project Management.

[6] Creswell, J. W. (2013). Qualitative inquiry and research design: Choosing among five approaches. Thousand Oaks, CA: Sage Publications.

[7] Cristina, C. and Raquel, T. (2016). Social Protection in Africa: Inventory of non-contributory Projecs. New York: International Policy Centre for Inclusive Growth / UNICEF. 
[8] Ika, L.A, Diallo,A.,\& Thuillier, D. (2010). Project Management in the International Development Industry: The project coordinator's perspective. International Journal of Managing Projects in Business, 2(8), 34 - 37.

[9] Karamaga,V, \& Rugege, D. (2014). Women's perceptions of the Girinka (one cow per poor family) project, poverty alleviation and climate resilience in Rwanda. Journal of empowering women for gender equity, 3(5), 53-64.

[10] Kim et, al 2011). Role of Families in Social and Economic Empowerment of Individuals. Social work research journals, 6(6), 56-84.

[11] Koster, K. (2010). International Project management, New Delhi:Vivek Mehra.

[12] Kothari, C. R. (2011). Research methodology: Methods and techniques (2nd ed.). Retrieved from http://books.google.com on $12^{\text {th }} / 03 / 2020$

[13] Matiwane, K., \&Terbinanche, U. (2012). The influence of beneficiary needs on project success or failure in the North West, South Africa.

[14] Mnaranara, T. (2010). The importance of community participation in an ongoing Constructions of Primary Schools. A case study of Mlali and Mzumbe ward, University of Agder.

[15] National Institute of Statistics of Rwanda (2015), Rwanda Poverty Profile Report, Integrated Household Living Conditions Survey Enquête Intégrale sur les Conditions de Vie des Ménages[EICV] 2013/14

[16] National Institute of statistics of Rwanda. (2011). Living conditions Survey, Kigali: MINECOFIN.

[17] Ntanyoma, R.D. (2010). The effect of livestock production on poor and smallholder farmers income in Rwanda. Pretoria: International Institute of Social Studies.

[18] Oluwatayo, J. (2012). Validity and reliability issues in educational research. Journal of Educational and Social Research 2, 391-400.

[19] Plummer, M. G., Cheong, D and Hamanaka, S. (2010). Methodology for Impact Assessment of Free Trade Agreements ${ }^{\mathrm{ee}}$, Asian Development Bank. Project Management Tips.

[20] Roll, S. \& Jean, E. (2014). Financially Vulnerable Families and the Child Care Cliff Effect. Poverty Journal, 9(3), $169-187$.

[21] Serrador, P. (2013). The Relationship between Project Success and Project Efficiency. Dubrovonic: World Congress. Study of Managers in Two Countries. Journal of Business Research, 8(15), 9 - 24

[22] Tenstep, I. (2012). Poor project communication will cause many projects to end unsuccessfully:

[23] Umworozi (2013). Umushyikirano Implementation Report of the 7th National Dialogue 2010- English

[24] UNICEF. (2011). Case Study on Narrowing the Gaps for Equity Rwanda, One Cow per Poor Family: Reaching the most marginalized in Rwanda

[25] Uwamahoro, M. G. (2012). Effect of implementation of project plans on project's goals achievements. Kigali: Mount Kenya University.

[26] Vincent and Denis (2014). Human Capacity Building in Manufacturing Sector: A Factor to Industrial Growth in Nigeria. International Journal of Social, Management, Economics and Business Engineering, 8 (3), $849-854$.

\section{AUTHORS}

First Author - Emmanuel Biringiro, School of Business and Economics, Mount Kenya University, Kigali, Rwanda Second Author - Dr. Ernest Safari, School of Tourism and Hospitality Management, Mount Kenya University, Kigali, Rwanda 